\title{
食品残さを成分表に基づき配合した養豚用リサイクル飼料の 組成および栄養価の設計値と実測值の比較
}

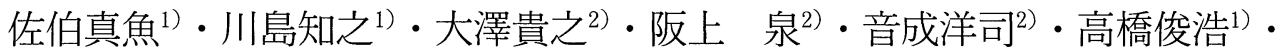 \\ 丹羽美次 ${ }^{3)}$ ・望月辰起 ${ }^{3)} \cdot$ 山本心平 $\left.{ }^{3}\right) \cdot$ 渡邊敬一 ${ }^{3)}$ ・矢後啓司 ${ }^{4)}$ ・青木 稔 ${ }^{5)}$ ・

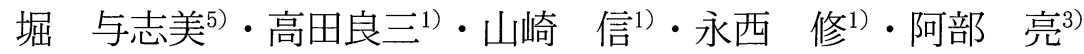 \\ 1) 畜産草地研究所, 茨城県つくば市池の台 2，305-0901 \\ 2)（有）ぴゅポーク，神奈川県平塚市岡崎 1616-2，259-1212 \\ 3) 日本大学生物資源科学部, 神奈川県藤沢市亀井野 1866, 252-8510 \\ 4) (財) 畜産生物科学安全研究所, 神奈川県相模原市橋本台 3-7-11, 229-1132 \\ 5) 神奈川県畜産研究所，神奈川県環境農政部，神奈川県海老名市本郷 3750，243-0417
}

(2004 年 4 月 22 日受付, 2004 年 8 月 31 日受理)

\begin{abstract}
要 約 食品残さ由来飼料のみで豚を飼養するような給与形態を想定して飼料成分表と 食品成分表の值をむとに各種食品残さの配合設計を行い，実際に各種食品残さを収集し， 乾燥飼料として調製し，それらの組成抢よび栄養価の推定值の有効性を検討した。素材の 収集は神奈川県平塚市を収集地域とし, ごはん類, パン類, 麺類, ライ麦糠, ビール粕, 魚類, 豆腐類, オカラ, 野菜屑を飼料化素材として供試した。これらの組成・栄養価につ いて, 残さの品目別に, 飼料成分表むしくは食品成分表から計算基礎值を抽出し, その值 をもとに 3 種類の配合設計を行った。これらについて各 45 日間以上, 素材の収集と乾燥飼 料化を行い, 各 $900 \mathrm{~kg}$ 以上の乾燥飼料を得た。その組成分析を行うとともに, LWD 種, 計 15 頭（平均体重 $47.2 \mathrm{~kg}$ ）を供試して消化試験を行い, 得られた組成および栄養価の実 測值と飼料設計時の設計值を比較した。その結果, 飼料成分表には記載されていない食品 残さ類の飼料利用に際して, 食品成分表の值と組み合わせて組成を推定することは有効で あった。栄養価 (TDN) については, 予測值に土3\%程度の誤差が生じる。またアミノ酸に ついてもリジン含量の実測值が設計值を下回ったため, 必要に応じて安全率を見込んだ配 合設計が必要であると考えられた。原材料の組成を抜き取りサンプリングによって測定し てむ，今回の条件下では予測の精度は必ずしも高まらなかった。
\end{abstract}

Validation of Chemical Composition and Nutritive Value of Feed for Swine Formulated from Co-products According to the Values Derived from the Standard Tables of Food and Feed Composition

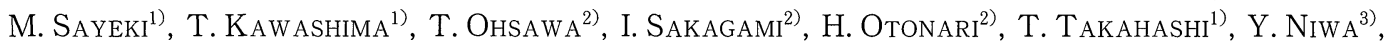

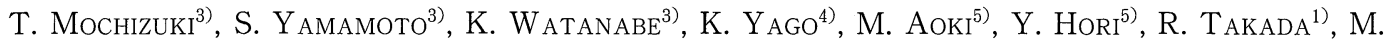
YAMAZAKI $^{1)}$, O. ENISHI ${ }^{1)}$ and A. ABE ${ }^{3)}$

1) National Institute of Livestock and Grassland Science, Tsukuba-shi, Ibaraki, 305-0901

${ }^{2)}$ Pure Pork Ltd. 1616-2 Okazaki, Hiratsuka-shi, Kanagawa, 259-1212

${ }^{3)}$ Nihon University, College of Bioresource Sciences, 1866 kameino, Fujisawa-shi, Kanagawa, $252-8510$

4) Research Institute for Animal Science in Biochemistry \& Toxicology, 3-7-11 Hashimotodai, Sagamihara-shi, Kanagawa, 229-1132

5) Livestock Industry Research Institute, Kanagawa Prefecture, 3750 Hongo, Ebina-shi, Kanagawa, 243-0417 
2004,12 月

\section{緒}

\section{言}

2001 年の「食品循環資源の再生利用等の促進に 関する法律」の施行および 2002 年の「バイオマ ス・ニッポン総合戦略」の閣議決定に相前後し て, 国内に抢ける食品残さの飼料利用が推進され

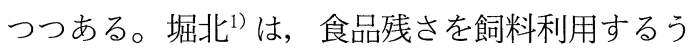
えでの必要条件として, 食品残さの栄養的価值を 日本標準飼料成分表 2) (以下, 飼料成分表), 日本 食品標準成分表 ${ }^{3)}$ (以下, 食品成分表) 等によっ て, 組成と栄養価を判断することを挙げている。 しかし, 食品残さ類の組成と栄養価のデー夕は完 備されているとは言い難い。飼料成分表には，国 内の特徴的な食品残さである, ごはん類残さ, 麺 類残さ, 雑多な野菜屑類や, 魚類残さ, 豆腐等の 組成・栄養価が含まれておらず，また食品成分表 に記載されている組成は，七トの可食部の值であ り, 必ずしも廃棄部の組成ではなく, 消化率む記 載はない。国内の利用現場では, 原材料に応じて 組成を推定し配合計算式をつくり栄養価を推定す ることが各所で行われている゙)が，実際にその組 成の実測值や栄養価の確認は困難であり, 試行錯 誤をしつつ給与している現状がある。

給与飼料中に占める食品残さ由来リサイクル飼 料の割合は, 数パーセントと非常に少ない割合で 使用する形態から, 給与量のほぼ $100 \%$ をリサ クル飼料で賄う形態まで多様である。養豚業にお いてリサイクル飼料を用いる動機は, 肥育豚生産 費の約 6 割を占める飼料費) の削減のためという ことが最む大きい。一般に食品残さの給与割合が 多くなり $100 \%$ に近づくほど，飼料費は低減され るが, 同時に組成と栄養価が变動し要求量に合わ ないリスクは高くなる。

食品残さの飼料利用を規模の面から分類する と, 1 日50トン以上の規模で多様な食品残さを収 集して飼料利用する場合 $\left.{ }^{6}\right)$ と, 1 日に数百キロか ら数卜ン程度の単位で利用する小規模での利用が ある。利用のスケールが大きい場合には, 素材 個々の組成の日間変動が大きくてあ, その組成は 一定值に収斂してくる7)。その反対任利用の規模 が小さくなれば, 素材の組成と栄養価の変動の影 響は大きくなるため, その組成汃ら栄養価を推定
日豚会誌 41 巻 4 号

する必要性屯高まる。原材料の分析をして実測值 から推定する場合む，変動がある残さをさらに抜 き取り法でサンプリングせざるを得ない。

本研究では, 小規模で収集した食品残さを原料 として飼料を製造し，それのみで豚を飼養する形 態を想定して, 実際に各種食品残さを収集し, 飼 料成分表, 食品成分表の值をむとに, 各種残さ類 の組成・栄養価加ら配合設計を行い, 乾燥飼料之 して調製し, 成分分析と消化試験の結果との比較 加ら，その推定值の有効性について検討した。

\section{材料および方法}

\section{1. 素材の収集と配合設計}

神奈川県平塚市を収集地域とし，レストランの セントラルキッチン, パン製造業, 精麦業, ビー 儿製造業および豆腐製造業の事業所から排出され た, ごはん類, 湎類, 野菜屑, 魚類, パン類, ラ イ麦糠, ビール粕, 豆腐類招よびオカラを飼料化 素材として供試した。セントラルキッチンは, 複 数の事業所の厨房機能が一か所にま之まった施設 であり，その調理品を各事業所に配送する。

原材料の組成について, 品目別に以下の基準を 設定し, 飼料成分表之食品成分表, アミノ酸組成 表8) から, 計算基礎值を抽出した。両成分表から 抽出可能な項目は両者から抽出し比較し, 適切と 考えられる值を採用した。

ごはん類：食品成分表の中の「水稲めし（精白 米)」の値を用いた。パン類 : 飼料成分表の「パン 屑 (乾)」の值と, 食品成分表の「食パン（市販 品)」の値を用いた。麺類: 食品成分表の「マカロ ニ・スパゲッティ（ゆで）」，「そば（ゆで）」,「う ごん（ゆで）」,「中華めん（ゆで）」の值を乾物中 含量にしたうえで平均值を求め, 麺類の值とし た。ライ麦糠 : 飼料成分表の「フスマ（大麦荒又 カ)」を使用した。ビール粕 : 飼料成分表の「ビー ル粕（生）」を使用した。豆腐類：食品成分表の 「木綿豆腐」の值を使用した。オカラ : 食品成分表 の「お加ら (旧来製法)」と, 飼料成分表の「トゥ フ粕 (生)」および「同 (乾)」の組成の平均值と を用いた。野菜類：農林水産省統計表 ${ }^{9)}$ による, 2000 年の出荷量が 50 万トン以上で，な扔かつ食 品成分表, アミノ酸組成表に記載がある品目を抽 
出してその平均値を求めた。また, 飼料成分表記 載の「ダイコン (根)」,「ニンジン (根)」,「バレ イショ (生, 芋)」,「ダイコン葉」,「ハクサイ外 葉」,「キャベッ(外葉む含む)」の組成および TDNの平均值をとった。魚類 : 農林水産省統 計 ${ }^{10)}$ に基づいた 2000 年の貝類・海藻類を除いた 品目別上場水揚量から，年間 10 万トン以上の上 場水揚量 (生鮮品十冷凍品) があり, 食品成分表, アミノ酸組成表に記載がある品目を抽出してその 平均值を求めた。また, 飼料成分表の「魚粉（ホ ワイトフィッシュミール)」,「魚粉 (CP 65\%)」, 「魚粉 (CP 60\%)」, 「魚粉 (CP 55\%)」, 「魚粉 (CP $50 \%) 」 の$ 平均值を求めた。アミノ酸組成表の乾物 率, 粗蛋白質, 粗脂肪の值は, 四訂食品成分表に 基づいて記載されている。そのために五訂版の値 との間で成分含量が異なり矛盾が生じる箇所は五 訂版の乾物率に従って含量を補正した。

可消化養分総量 (TDN) の推定は, 飼料成分表 に記載されている值を用いた。具体的には，パン
は「パン屑 (乾)」の TDN 值を, 野菜類は,「ダイ コン (根)」,「ニンジン (根)」,「バレイショ (生, 芋) 」,「ダイコン葉」,「ハクサイ外葉」,「キャベッ (外葉屯含む)」の TDN の平均值をとり, オカラ は,「トウフ粕 (生)」と「トウフ粕 (乾)」の平均 值を，魚類については，「魚粉（ホワイトフィッ シュミール)」, 「魚粉 (CP 65\%)」, 「魚粉 (CP $60 \%) 」$, 「魚粉 (CP 55\%)」,「魚粉 (CP 50\%)」の TDN 平均值を求めた。ごはんの TDN は飼料成 分表の精白米の $96.6 \%$ を使用し, 飼料成分表には 関連素材の記載のない豆腐, 麺類については, 食 品成分表の水稲めし (精白米) のエネルギー含量 に対する比率をこの $96.6 \%$ に乗じて， $125.5 \%$, $96.8 \%$ とした。

これらの組成（表 1, 表 2）を計算基礎値とし て, 食品残さをより多く使用可能な肥育スケ ジュールを想定して表 3 に示した 3 種の配合割合 をつくった。飼料 1 および 2 は肥育前期, 飼料 3 は肥育後期の飼い直しを想定した設計とした。

表 1. 飼料化素材の計算基礎值（一般成分，無機物，TDN）

Table 1. The standard values of chemical composition and total digestible nutrient (TDN) of food waste for the formulation of feed

\begin{tabular}{|c|c|c|c|c|c|c|c|c|c|c|}
\hline \multirow{2}{*}{ 素材 } & \multirow{2}{*}{ 食品むしくは飼料名称 } & \multirow{2}{*}{$\begin{array}{c}\text { 乾物, } \\
\%\end{array}$} & \multicolumn{3}{|c|}{ 乾物中\% } & \multicolumn{4}{|c|}{ 無機物，乾物中\% } & \multirow{2}{*}{$\begin{array}{c}\text { 乾物中 } \\
\% \\
\text { TDN }\end{array}$} \\
\hline & & & 粗蛋白質 & 粗脂肪 & 灰分 & $\mathrm{K}$ & $\mathrm{Ca}$ & $\mathrm{Mg}$ & $\mathrm{P}$ & \\
\hline ごはん & 水稲めし (精白米) $)^{1)}$ & 40.0 & 6.3 & 0.8 & 0.3 & 0.073 & 0.008 & 0.018 & 0.085 & 96.6 \\
\hline \multirow[t]{2}{*}{ パン } & パン屑 $(\text { 乾 })^{2)}$ & $62.0^{1)}$ & 14.6 & 5.2 & 2.7 & 0.170 & 0.070 & 0.030 & 0.130 & 99.0 \\
\hline & 食パン (市販品) $)^{1,3)}$ & 62.0 & 15.0 & 7.1 & 2.6 & 0.156 & 0.047 & 0.032 & 0.134 & 99.0 \\
\hline 麺類 & 麺類 ${ }^{1)}$ & 31.8 & 13.6 & 2.3 & 1.1 & 0.087 & 0.032 & 0.045 & 0.136 & 96.8 \\
\hline ライ麦糠 & フスマ $(\text { 大麦荒ヌカ })^{2)}$ & 88.8 & 7.4 & 3.0 & 6.5 & 0.510 & 0.150 & - & 0.180 & 42.3 \\
\hline ビール粕 & ビール粕 $(\text { 生 })^{2)}$ & 25.7 & 27.0 & 9.4 & 4.6 & 0.040 & 0.245 & 0.225 & 0.520 & 48.4 \\
\hline 豆腐 & 木綿豆腐1) & 13.2 & 50.0 & 31.8 & 6.1 & 1.061 & 0.909 & 0.235 & 0.833 & 125.5 \\
\hline \multirow[t]{2}{*}{ オカラ } & トウフ粕 $(\text { 生 })^{2)}$ & 20.7 & 27.4 & 12.7 & 4.5 & 1.200 & 0.370 & - & 0.340 & 71.4 \\
\hline & おから (旧来製法 $)^{1,3)}$ & 18.9 & 25.4 & 19.0 & 4.2 & 1.217 & 0.529 & 0.196 & 0.344 & 71.4 \\
\hline \multirow[t]{2}{*}{ 野菜類 } & 野菜類2,3) & 12.0 & 16.2 & 1.8 & 10.9 & 2.090 & 0.275 & 0.120 & 0.230 & 73.3 \\
\hline & 野菜類1) & 8.7 & 13.8 & 1.6 & 9.1 & 3.315 & 0.651 & 0.175 & 0.435 & 73.3 \\
\hline \multirow[t]{2}{*}{ 魚類 } & 魚粉2,3) & $30.2^{1)}$ & 66.1 & 10.3 & 21.6 & 0.682 & 6.660 & 0.246 & 3.670 & 74.4 \\
\hline & 魚類 ${ }^{1)}$ & 30.2 & 69.6 & 25.5 & 4.2 & 1.194 & 0.117 & 0.118 & 0.840 & 74.4 \\
\hline
\end{tabular}

1): 五訂日本食品標準成分表の值

2): 日本標準飼料成分表 (2001 年版) の値

${ }^{3)}$ : 本報告の設計值計算には不使用 
2004,12 月

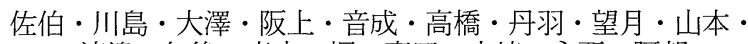

渡邊・矢後・青木 ・ 堀・高田・山崎・永西・阿部

日豚会誌 41 巻 4 号

表 2. 飼料化素材の計算基礎值（アミノ酸）

Table 2. The standard values of amino acids of food waste for the formulation of feed

\begin{tabular}{|c|c|c|c|c|c|c|c|c|c|}
\hline \multirow[b]{2}{*}{ 素 材 } & \multirow[b]{2}{*}{ 食品むしくは飼料名称 } & \multicolumn{8}{|c|}{ アミノ酸，乾物中\% } \\
\hline & & $\begin{array}{c}\text { アルギ } \\
\text { ニン }\end{array}$ & $\begin{array}{c}\text { ヒスチ } \\
\text { ジン }\end{array}$ & $\begin{array}{c}\text { イソロイ } \\
\text { シン }\end{array}$ & ロイシン & リジン & $\begin{array}{l}\text { メチオ } \\
\text { ニン }\end{array}$ & $\begin{array}{l}\text { フェニル } \\
\text { アラニン }\end{array}$ & $\begin{array}{l}\text { スレオ } \\
\text { ニン }\end{array}$ \\
\hline ごはん & 水稲めし (精白米) $)^{1)}$ & 0.51 & 0.17 & 0.27 & 0.53 & 0.23 & 0.16 & 0.34 & 0.22 \\
\hline \multirow[t]{2}{*}{ パン } & パン屑 $(\text { 乾 })^{2)}$ & 0.44 & 0.27 & 0.49 & 0.87 & 0.27 & 0.20 & 0.63 & 0.31 \\
\hline & 食パン (市販品) $)^{1,3)}$ & 0.52 & 0.38 & 0.61 & 1.18 & 0.39 & 0.27 & 0.82 & 0.48 \\
\hline 麺類 & 湎類1) & 0.58 & 0.34 & 0.52 & 1.00 & 0.36 & 0.24 & 0.72 & 0.41 \\
\hline ライ麦糠 & フスマ (大麦荒ヌカ) $)^{2)}$ & 0.44 & 1.50 & 0.28 & 0.47 & 0.35 & 0.15 & 0.30 & 0.32 \\
\hline ビール粕 & ビール粕 $(\text { 生 })^{2)}$ & 1.30 & 0.58 & 1.19 & 2.03 & 0.99 & 0.47 & 1.44 & 0.93 \\
\hline 豆腐 & 木綿豆腐1) & 4.04 & 1.47 & 2.72 & 4.41 & 3.38 & 0.74 & 2.87 & 2.06 \\
\hline \multirow[t]{2}{*}{ オカラ } & トウフ粕 $(\text { 生 })^{2)}$ & 1.64 & 0.85 & 1.22 & 2.12 & 1.69 & 0.42 & 1.32 & 1.11 \\
\hline & おから (旧来製法) $)^{1,3)}$ & 1.81 & 0.75 & 1.24 & 2.15 & 1.70 & 0.42 & 1.43 & 1.19 \\
\hline \multirow[t]{2}{*}{ 野菜類 } & 野菜類2,3) & 0.50 & 0.17 & 0.28 & 0.43 & 0.41 & 0.07 & 0.28 & 0.31 \\
\hline & 野菜類1) & 0.62 & 0.24 & 0.36 & 0.57 & 0.56 & 0.14 & 0.38 & 0.37 \\
\hline \multirow[t]{2}{*}{ 魚類 } & 魚粉2,3) & 4.10 & 1.65 & 2.71 & 4.69 & 4.80 & 1.84 & 2.56 & 2.79 \\
\hline & 魚類 ${ }^{1)}$ & 4.04 & 3.54 & 3.18 & 5.38 & 6.32 & 2.14 & 2.77 & 3.10 \\
\hline
\end{tabular}

1) : 五訂日本食品標準成分表の值

2): 日本標準飼料成分表（2001 年版）の值

${ }^{3)}$ : 本報告の設計值計算には不使用

表 3. 試験飼料の配合割合

Table 3. Ingredient of feedstuff

\begin{tabular}{lrrr}
\hline \hline 試 験 飼 料 & 1 & 2 & 3 \\
\hline 配合割合, 現物\% & & & \\
ごはん & 10 & 7 & 30 \\
パン & 5 & 5 & 22 \\
麺類 & 5 & 0 & 0 \\
ライ麦糠 & 15 & 5 & 1 \\
ビール粕 & 10 & 0 & 11 \\
豆腐 & 10 & 0 & 0 \\
オカラ & 15 & 50 & 16 \\
野菜類 & 20 & 20 & 15 \\
魚類 & 10 & 13 & 5 \\
計 & 100 & 100 & 100 \\
\hline 炭酸カルシゥム & 0.8 & 0.8 & 0.8 \\
塩化マグネシゥム & 0.3 & 0.3 & 0.3 \\
\hline
\end{tabular}

\section{2. 飼料製造}

飼料 1，2，3 の順番で乾燥飼料化し，それぞれ の製造期間中，毎日収集した。飼料調製には丹羽 $ら^{11)}$ および大澤ら ${ }^{12)}$ の報告と同一の装置を使用 した。原料投入から取り出しまで 6 日間かかった システムを本試験では 48 時間の発酵工程と 24 時 間の乾燥工程の計 3 日間の乾燥方式へと変更して 飼料調製を行った。1 日に現物として約 $70 \mathrm{~kg}$ を 投入し，投入時には $0.1 \mathrm{~kg}$ 単位で重量を測定して 配合した。丹羽らの報告11) のスタータと同様に複 合生菌酵素剂「バイオアッセイ液」((株)トータル ウェルネス研究所製）を材料現物の約 $0.1 \%$ 添加 した。また発酵条件の調整を目的として，炭酸力 ルシウム, 塩化マグネシウムを投入現物量の $0.8 \%$ と $0.3 \%$, 外付けで添加した。飼料 1 は, 2001 年 10 月 3 日から毎日連続的に装置に投入し 10 月 6 日 から製造飼料を取り出し，11月 19 日まで製造し た(45 日間)。飼料 2 は同年 11 月 16 日の投入開始 から 12 月 30 日の最終ロット取り出しまで 45 日 
間, 飼料 3 は 2002 年 1 月 8 日から 3 月 27 日（79 日間）まで製造し，その中から各飼料とも $200 \mathrm{~kg}$ ずつ抜き取ってそれぞれ酸化クロムを均一に混合 後, 分析用および消化試験用飼料として供試し た。

\section{3. 組成と栄養価の測定}

原材料は飼料 1 の製造期間中に適宜，数力所の 抜き取り法によりサンプリングし， $60^{\circ} \mathrm{C}$ で乾燥 後, 室温で風乾物とし, 一般成分と無機物含量を 測定した。2 回以上サンプリングした品目は，風 乾物を等量混合したものを分析に供した。調製後 の飼料 3 種類については, 一般成分, 無機物含量, アミノ酸組成を測定した。

栄養価の測定 (消化試験) には, 2 腹の LWD 三 元交雑種, 計 15 頭 (去勢雄 9 頭, 雌 6 頭, 平均体 重 $47.2 \mathrm{~kg}$ ）を供試した。1 飼料につき 5 頭（去勢 雄 3 頭，雌 2 頭）を配置し，予備飼育期間 10 日 間，本試験期間 4 日間で実施した。飼料の給与は 朝夕 2 回 (9:00，16:00) とし，1日の給与量は 個体ごとに乾物として体重の $4 \%$ の制限給与とし た。一部 $4 \%$ 量を摂取出来なかった個体は $3 \%$ 以 上の制限給与とした。去勢雄は代謝ケージに収容 し，雌は個別豚房で，酸化クロムを用いた指示物 質法による消化試験（朝昼夜に部分採糞）を行い， 採取した糞は $60^{\circ} \mathrm{C}$ で 48 時間乾燥後，5 日間以上 室温に置き，水分を平衡させた風乾物の状態にし て，粉砕後分析に供し，消化率および可消化養分 総量（TDN）を算出した。

\section{4. 分 析}

一般成分の分析は，常法 ${ }^{13)}$ で行い，無機物は湿 式灰化後, 原子吸光分光光度計 (島津) を用いて, カルシゥム，マグネシゥム，カリウムを測定し， リンバナドモリブデン酸法によってリンを測定し た ${ }^{14)}$ 。酸化クロムはリン酸カリ試薬法 ${ }^{15)}$ で定量し た。アミノ酸は, 試料を $6 \mathrm{~N}$ 塩酸で $110^{\circ} \mathrm{C}, 24$ 時間 の酸加水分解後, アミノ酸分析計（日立アミノ酸 自動分析計 L-8500A）で測定した。含硫アミノ酸 については, 酸加水分解の前に $0^{\circ} \mathrm{C}, 16$ 時間の過 ギ酸酸化を行った。

\section{5. 設計值と実測值}

3 種類の飼料の発酵乾燥処理前の食品残さの現 物配合割合（表 3) から，水分，粗タンパク質，粗
脂肪, 粗灰分の含量, $\mathrm{TDN}$, 無機物 ( $\mathrm{K}, \mathrm{Ca}, \mathrm{Mg}$, P) 含量, アミノ酸組成の設計值（1)-(3)）を以下 のように算出し, 飼料の実測值（4)）と比較した。 (1) : 乾物率抢よび組成ともに表 1 ，表 2 の計算基 礎值を用いて計算した設計值，(2)：抜き取りサン プリングによる原材料の乾物率の実測值を計算に 使用し, 組成については，表 1 , 表 2 の計算基礎值 を用いて計算した設計値，(3)：抜き取りサンプリ ングにより測定した原材料の乾物率およびその他 の組成の実測値を用いて計算した設計値, (4) : 飼 料の実測值，について值を比較した。原材料では TDN およびアミノ酸の実測を行っていないた め, (3)についての検討はしなかった。

\section{結果}

\section{1. 素材の収集と飼料製造}

麺類残さのサンプリングは出来ず，分析してい ない。飼料の製造期間中は，素材となる各種残さ は1日も不足することなく収集され飼料化され た。飼料 1 の原料食品残さの総投入量は 45 日間 で $3,187.6 \mathrm{~kg}$, 総取出量は $1,051.1 \mathrm{~kg}$ であった。飼 料 2 は 45 日間で同 $3,232.7 \mathrm{~kg}, 909.3 \mathrm{~kg}$, 飼料 3 は 79 日間で $5,693.6 \mathrm{~kg}, 1,879.2 \mathrm{~kg}$ であった。飼 料の乾燥時の温度（製造 3 日目）は品温として $80^{\circ} \mathrm{C}$ になるよう初期設定した。しかし温度調整が うまくいかなかったため, 確実に $80^{\circ} \mathrm{C}$ 以上とな るような設定をし, $110^{\circ} \mathrm{C}$ までの範囲の温度变動 下で製造を行った。

\section{2. 組成と栄養価}

各種食品残さの組成の基礎値を表 1 と表 2 に示 した。年間出荷量の多い順番に, ばれいしょ(じゃ がいも)，だいこん，キャベッ，たまねぎ，はくさ い, トマト，にんじんが抽出され，これらについ て食品成分表に記載されている組成の平均值を求 め，野菜屑類とした。また，飼料成分表からは， 上記のうち記載のあった「ダイコン（根）」，「ニン ジン (根)」,「バレイショ (生, 芋)」,「ダイコン 葉」,「ハクサイ外葉」,「キャベッ（外葉も含む）」 の平均值を求めた。魚介類は, 年間上場水揚量の 多い順番で, かつお，さば類，すけとうだら，か たくちいわし，さんま，まあじ，ほっけ，まいわ しが抽出され，これらの組成の平均值を求めた。 
食品成分表之飼料成分表の両者加值を抽出し た項目について，パンはほぼ同じ值を示した。才 カラの粗脂肪含量は約 $6 \%$ 単位の差が認められ, 野菜類は水分之粗タンパク質含量に $2.4 \%$ 単位の 差が見られた。食品成分表から抽出した魚の一般 成分值は, 飼料成分表から抽出した魚粉類の值に 比べて, 粗タンパク質が $3 \%$ 単位, 粗脂肪含量が $15 \%$ 単位多く, 粗灰分含量が $17 \%$ 単位少なかっ た。

抜き取りサンプリングして分析した原材料の組 成を表 4 に示した。表 1 の值と比較すると乾物率 は大部分が異なり, 魚では $10 \%$ 単位, パンで $8.9 \%$ 単位あの差であった。乾物中の組成には乾 物率ほどの違いは生じなかった。

製造した乾燥飼料の組成を表 5 に，それらの消 化試験結果を表 6 に示した。一般的な肥育豚用配 合飼料に比べて, 粗タンパク質, 繊維(NDF, ADF) 含量が多く, 消化率は, 全体的に低い值を示した。 可消化養分総量（TDN） は飼料 1，2，3の順に 68.4\%, 73.6\%，83.9\%であった。

\section{3. 設計値と実測值の比較}

表 7 に一般成分, TDN, 無機物について, 飼料 の設計值と実測值の比較を, 表 8 にアミノ酸につ いて同様に示した。

一般成分含量について, 実測值（表 7, (4)）と比
較した設計值（表 7，(1)-(3)）は概称 $2 \%$ 単位以内 の誤差であった。しかし，飼料 3 の粗タンパク質 についての設計值は実測値よりあ $4 \%$ 単位程度低 い值であった。TDNについてあ, 飼料 1 と 2 は, 実測值に比べて設計值は約 $3 \%$ 単位低く, 飼料 3

表 5. 試験飼料の組成

Table 5. Chemical composition of the experimental diets

\begin{tabular}{lrrr}
\hline \hline & \multicolumn{3}{c}{ 試 験 飼 料 } \\
& \multicolumn{1}{c}{1} & \multicolumn{1}{c}{2} & \multicolumn{1}{c}{3} \\
\hline $\mathrm{pH}$ & 4.49 & 4.66 & 4.06 \\
乾物, \% & 96.1 & 97.9 & 97.7 \\
乾物中\% & & & \\
粗蛋白質 & 21.4 & 25.9 & 19.5 \\
粗脂肪 & 9.1 & 8.8 & 5.7 \\
粗灰分 & 7.5 & 7.9 & 5.8 \\
$\mathrm{NDF}^{1)}$ & 34.9 & 37.6 & 27.3 \\
$\mathrm{ADF}^{2)}$ & 13.8 & 15.6 & 9.9 \\
$\mathrm{NFC}^{3)}$ & 27.1 & 19.8 & 41.7 \\
\hline
\end{tabular}

1): 中性デタージェント繊維

2) : 酸性デタージェント繊維

3) : 非繊維性炭水化物＝有機物一粗蛋白質一粗 脂肪一NDF

表 4. 飼料化素材の組成実測值

Table 4. Dry matter and chemical composition of food wastes and food processing by-products in Hiratsuka city (Kanagawa pref., Japan)

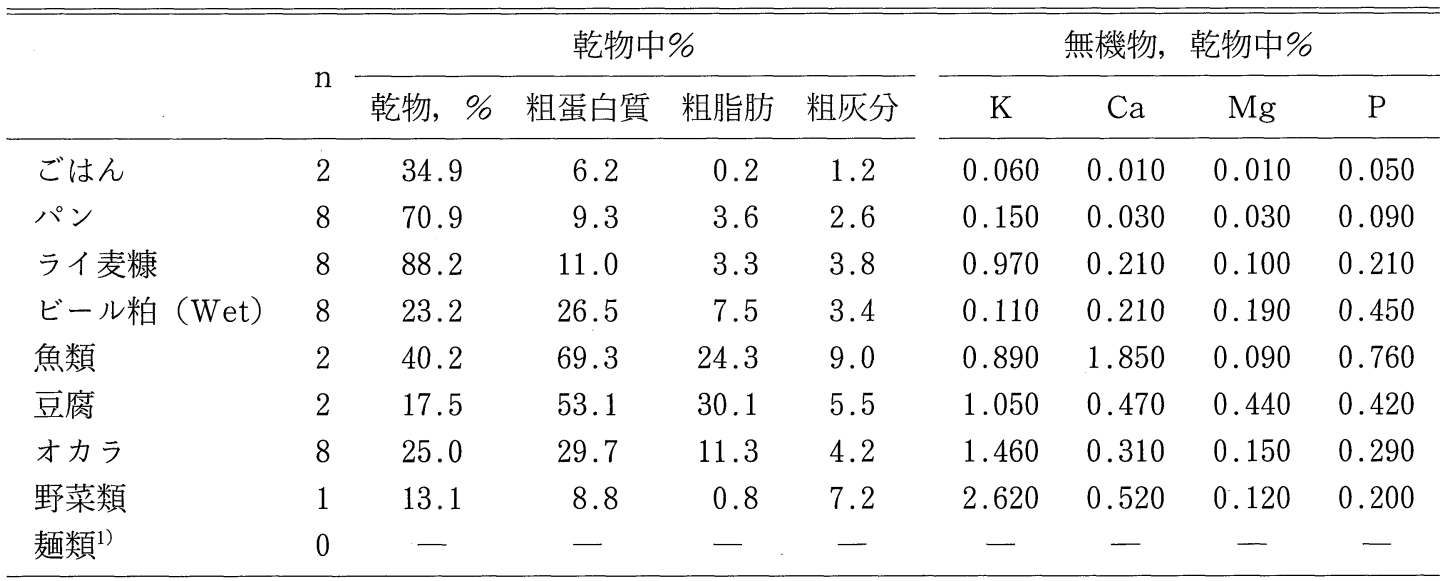

1): サンプリングしていない 
表 6. 試験飼料の消化率と栄養価

Table 6. Digestibility and total digestible nutrient $(\mathrm{TDN})$ of experimental diets

\begin{tabular}{lccc}
\hline \hline 試 験 飼 料 & 1 & 2 & 3 \\
\hline 消化率, \% & & & \\
$\quad$ 乾物 & 59.8 & 65.9 & 79.8 \\
$\quad$ 有機物 & 63.6 & 69.8 & 82.6 \\
$\quad$ 粗脂肪 & 84.5 & 85.2 & 85.9 \\
$\quad$ 粗蛋白質 & 69.0 & 75.2 & 74.2 \\
栄養価, 乾物中\% & & & \\
DCP & 14.8 & 19.5 & 14.5 \\
TDN & 68.4 & 73.6 & 83.9 \\
\hline
\end{tabular}

の場合は約 3\% 単位高かった。

無機物類について，K および $\mathrm{Ca}$ は実測值（表 7, (4)）より屯設計值（表 7, (1)-(3)）は低い值であ り，それと反対に $\mathrm{Mg}$ は高い值となった。P の実 測値はほぼ設計值通りとなった。

必須アミノ酸の設計值（表 8, (1)-(3)）と実測值 （表 8, (4)）との間は, 飼料 1 および飼料 2 のヒス チジンで $0.64 \%$ 単位（(2)-(4)), $0.44 \%$ 単位（2)(4)）の差, 飼料 2 のリジンで $0.38 \%$ 単位 (2)-(4)) の差が大きかった。その他のアミノ酸の実測值之 設計值との差はそれ以下であった。 3 種類の飼料 全てについて, リジンの実測值（表 8, (4)）は設計 值（表 8，(1)(2)）を下回っていた。

\section{考察}

\section{1. 飼料評価}

本試験の 3 種類の飼料は以下の考えに基づき設 計した。 $1 ， 2$ を肥育前期用， 3 を肥育後期の飼い なおし用の例として想定した。飼料 1 : ライ麦糠 を乾物として $36 \%$ 使い, 糠類と混合し TDN が比 較的低い設計とした。飼料費を低減したことで, ある程度肥育期間が延びても構わない場合の飼料 を想定した。飼料 2 : 雑多な食品残さ混合物の特 徵である高タンパク質 $(25 \%)$ で，なおかつ不飽 和脂肪酸の多い飼料を想定して，オカラを現物と して $50 \%$ 使った。粗脂肪含量は $10 \%$ を超えない ようにした。飼料 1 と 2 は，粗脂肪含量が比較的
表 7. 一般成分, TDN, 無機物の設計値之 実測值の比較，乾物中\%

Table 7. Calculated and surveyed values of chemical composition $(\% \mathrm{DM})$ at experimental diet

\begin{tabular}{|c|c|c|c|c|}
\hline 試験飼料 & & 1 & 2 & 3 \\
\hline \multirow[t]{4}{*}{ 粗蛋白質 } & (1) & 18.5 & 24.6 & 15.6 \\
\hline & (2) & 20.4 & 26.4 & 16.7 \\
\hline & (3) & 21.1 & 26.8 & 14.6 \\
\hline & (4) & 21.4 & 25.9 & 19.5 \\
\hline \multirow[t]{4}{*}{ 粗脂肪 } & (1) & 7.1 & 9.7 & 5.2 \\
\hline & (2) & 7.9 & 10.3 & 5.7 \\
\hline & (3) & 7.3 & 9.4 & 4.6 \\
\hline & (4) & 9.1 & 8.8 & 5.7 \\
\hline \multirow[t]{4}{*}{ 粗灰分 } & (1) & 7.7 & 8.3 & 5.5 \\
\hline & (2) & 7.7 & 7.9 & 5.6 \\
\hline & (3) & 7.1 & 8.1 & 5.8 \\
\hline & (4) & 7.5 & 7.9 & 5.8 \\
\hline \multirow[t]{4}{*}{ TDN } & (1) & 65.2 & 70.1 & 85.5 \\
\hline & (2) & 66.6 & 70.6 & 85.4 \\
\hline & (3) & - & - & - \\
\hline & (4) & 68.4 & 73.6 & 83.9 \\
\hline \multicolumn{5}{|l|}{ 無機物 } \\
\hline \multirow[t]{4}{*}{$\mathrm{K}$} & (1) & 0.64 & 0.94 & 0.38 \\
\hline & (2) & 0.74 & 1.03 & 0.46 \\
\hline & (3) & 0.85 & 1.09 & 0.44 \\
\hline & (4) & 0.89 & 1.07 & 0.51 \\
\hline \multirow[t]{4}{*}{$\overline{\mathrm{Ca}}$} & (1) & 1.11 & 1.40 & 0.99 \\
\hline & (2) & 1.07 & 1.25 & 0.96 \\
\hline & (3) & 1.24 & 1.51 & 1.02 \\
\hline & (4) & 1.89 & 1.88 & 1.43 \\
\hline \multirow[t]{4}{*}{$\mathrm{Mg}$} & (1) & 0.29 & 0.39 & 0.27 \\
\hline & (2) & 0.28 & 0.36 & 0.27 \\
\hline & (3) & 0.31 & 0.34 & 0.25 \\
\hline & (4) & 0.24 & 0.25 & 0.17 \\
\hline \multirow[t]{4}{*}{$\mathrm{P}$} & (1) & 0.29 & 0.33 & 0.20 \\
\hline & (2) & 0.32 & 0.35 & 0.22 \\
\hline & (3) & 0.27 & 0.30 & 0.16 \\
\hline & (4) & 0.28 & 0.30 & 0.19 \\
\hline
\end{tabular}

(1): Table 1 の組成を基礎にして計算した設計 值

(2): Table 1 の組成を基礎にして計算した設計 值（乾物率のみ素材の実測値）

(3) : 素材の実測值を基礎にして計算した設計值

(4): 試験飼料の実測値 
表 8. アミノ酸組成の設計值と実測值の比較, 乾物中\%

Table 8. Calculated and surveyed values of amino acid contents (\%DM) of experimental diet

\begin{tabular}{|c|c|c|c|c|}
\hline 試験飼料 & & 1 & 2 & 3 \\
\hline \multirow[t]{4}{*}{ アルギニン } & (1) & 1.08 & 1.47 & 0.79 \\
\hline & (2) & 1.20 & 1.57 & 0.84 \\
\hline & (3) & - & - & - \\
\hline & (4) & 1.05 & 1.37 & 0.92 \\
\hline \multirow[t]{4}{*}{ ヒスチジン } & (1) & 1.12 & 1.09 & 0.46 \\
\hline & (2) & 1.16 & 1.14 & 0.50 \\
\hline & (3) & - & - & - \\
\hline & (4) & 0.52 & 0.70 & 0.44 \\
\hline \multirow{4}{*}{ イソロイシン } & (1) & 0.80 & 1.07 & 0.63 \\
\hline & (2) & 0.88 & 1.15 & 0.67 \\
\hline & (3) & - & - & - \\
\hline & (4). & 0.77 & 0.87 & 0.66 \\
\hline \multirow[t]{4}{*}{ ロイシン } & (1) & 1.36 & 1.84 & 1.10 \\
\hline & (2) & 1.51 & 1.97 & 1.17 \\
\hline & (3) & - & - & - \\
\hline & (4) & 1.44 & 1.69 & 1.33 \\
\hline \multirow[t]{4}{*}{ リジン } & (1) & 1.13 & 1.69 & 0.70 \\
\hline & (2) & 1.29 & 1.85 & 0.78 \\
\hline & (3) & - & - & - \\
\hline & (4) & 0.97 & 1.31 & 0.62 \\
\hline \multirow[t]{4}{*}{ メチオニン } & (1) & 0.40 & 0.54 & 0.30 \\
\hline & (2) & 0.44 & 0.58 & 0.32 \\
\hline & (3) & - & - & - \\
\hline & (4) & 0.33 & 0.33 & 0.27 \\
\hline \multirow[t]{4}{*}{ フェニルアラニン } & (1) & 0.84 & 1.11 & 0.72 \\
\hline & (2) & 0.92 & 1.18 & 0.76 \\
\hline & (3) & - & - & - \\
\hline & (4) & 0.94 & 1.09 & 0.87 \\
\hline \multirow[t]{4}{*}{ スレオニン } & (1) & 0.73 & 1.02 & 0.52 \\
\hline & (2) & 0.81 & 1.10 & 0.56 \\
\hline & (3) & - & - & - \\
\hline & (4) & 0.90 & 1.23 & 0.74 \\
\hline
\end{tabular}

(1), (2), (3), (4): Table 7 を参照.

多く, 不飽和脂肪酸が多い特徵をむつ。飼料 3 : リサイクル飼料のみで肥育後期に飼いなおしを行 うための飼料設計とした。ごはんとパンで乾物と
して $70 \%$ とし，高でんぷん設計とした。不飽和脂 肪酸の多いオカラは乾物として $11 \%$ 以下に抑え, 同様に軟脂, 黄豚のリスクが上昇する魚類は乾物 として $6 \%$ 以下とした。リジン含量を飼料 1,2 に 比べて少なくし，肥育後期の水準とした。肥育試 験については大澤ら ${ }^{16)}$ が報告するが，今回の飼料 設計では，ミネラル・ビタミン類の要求量は考慮 しなかった。そのため肥育試験時には，不足分の 添加が必要であった。マクロミネラルについて は, リンの添加が必要な水準であった。

肥育後期において，でんぷんを多給し，肉の脂 肪酸組成を不飽和脂肪酸から飽和脂肪酸に切り替 える飼いなおしを前提として, 肥育前期には食品 残さとして供給される, 高タンパク, 高脂肪でか つ不飽和脂肪酸の多い素材で肥育して, 後期に, パン，ごはんを多給し，粗脂肪含量す $5 \%$ 程度に 押さえ込んだ飼料によって飼い直しを行うという 考え方で行った。

粗タンパク質の消化率は, $69.0 \%, 75.2 \%, 74.2 \%$ であった。乾燥飼料化には, タンパク質の熱変性 による消化率の低下が懸念されるが, 各地の食品 残さ乾燥飼料に招ける粗タンパク質消化率 ${ }^{17)}$ と 比較すると高く, また, オカラ, 野菜屑類, 麦糠 類の粗タンパク質消化率があともと低(2)ことあ 鑑みると, 本試験の加熱乾燥処理がタンパク質消 化率に及ぼした影響は少なかったと考えられる。

\section{2. 設計值と実測值の比較}

計算基礎値として用いた品目のうち, 食品成分 表と飼料成分表の両方から抽出したのは，パン 屑, オカラ, 野菜屑類, 魚類であり, パン屑は両 者の組成に顕著な違いは認められなかった。数種 類の平均値を算出して求めた野菜屑類における粗 タンパク質には $2.4 \%$ 単位の差が認められた。し かし，これらの乾物率は $12.0 \%, 8.7 \%$ と低いた め, 本配合設計全体への影響は小さいと考えられ る。野菜屑を多量に配合する場合には検討が必要 だろう。本試験の素材はヒトの可食部の量が目 立ったために食品成分表の值を用いた。オカラの 水分・組成変動は非常に大きい11) ので, 今回は素 材の実測值（表 4）に基づき脂肪含量が近いほう の飼料成分表の值を用いた。配合割合を多くする 場合には, 計算基礎値 (表 1) のみでは推定誤差が 
大きくなる可能性がある。魚類に関しても，食品 成分表に記載されている可食部の值と，飼料成分 表の魚粉類の平均值とは脂肪および粗灰分が大き く異なった。本研究で使用した魚類残さは，レス トランのセントラルキッチンから排出される切り 身部分が多く含まれる残さであり，魚腸骨を主原 料とする魚粉とは異なると判断したため, 食品成 分表から抽出した值を使用した。魚類残さを利用 する場合には, それが魚の切り身部分なのか, 魚 腸骨部分なのか，の見極めが必要であろう。

今回測定した一般成分全般については, 設計值 （表 7，(1)-(3)）と実測值（表 7, (4)）は近似した值 を示した。飼料 3 のみ, 粗タンパク質含量の実測 值（表 7, (4)）が設計值（表 7, (1)-(3)）を大きく 上回ったことは, パンの乾物量の実測值 (表 4) と 計算基礎值（表 1) が大きく異なった（8.9\% 単位） ことと,さらに粗タンパク質含量が計算基礎値 （表 1）の $14.6 \%$ に比べて, 実測値（表 4）は 9.3\% と少なく, 飼料 3 において, 配合中のパンの割合 が多くなったことで, 誤差が拡大し, 設計值（表 7, (1)-(3)）之実測值（表 7, (4)）は近似した值では なかった。アミノ酸について日本飼養標準の理想 パターン18) と比較すると, リジンが第一制限アミ ノ酸となっており，いずれの飼料あ実測值（表 8, (4)）は，設計值（表 8, (1) (2)）を下回っていた。そ のため, アミノ酸については安全率を見込むこと は必要である。TDN については，組成の計算基 礎值（表 1）にさらに推定を重㱛ることになるた め，組成の場合に比べると誤差は大きかった。飼 料を不断給飼した場合に豚はTDN 含量に応じて 飼料摂取量を調節する。そのため今回のような $3 \%$ 単位程度の TDN 含量の不足では, 安全率は あまり問題とはならないと考える。安全率をみて TDN 含量を高めると飼料摂取量が減り，アミノ 酸の不足が懸念され, また, 厚脂の生じる可能性 む高くなる。

無機物の結果は，素材の計算基礎値の影響だけ ではなく, 外付けで添加した炭酸カルシウムと塩 化マグネシゥムの投入誤差の影響を受けた可能性 ああるが, 基本的には微量ミネラル, ビタミンも 含めて要求量を充足するために添加を前提とする 必要がある。
今回のサンプリング条件では原材料の乾物およ び組成を実測して計算した場合にも，精度の向上 は認められなかった。毎日排出されてくる各種の 残さ類の組成を実測する場合む，サンプリング時 に均一に混合し，縮分するような条件で採取する ことは非常に困難であり, 数力所の抜き取り法で 一部をサンプリングせざるを得ない。そのための サンプリングエラーは避けられず，同時に，素材 の日間変動が加わるため, その全体の成分を把握 することは容易ではない。今回とほぼ同一の収 集条件で行った報告11)では，それぞれ同一の排出 元から， 6 日間採取したパン屑の水分は $27.3 \%$ か ら $37.6 \%$ の範囲で変動し，オカラは $68.1 \%$ から $74.3 \%$, 魚を主体としたレストランの調理残さは $66.1 \%$ から $85.0 \%$ と変動幅は大きい。本試験の製 造飼料は，製造期間中，連続的に製造し，総製造 量の約 5 分の 1 量（飼料 3 は 10 分の 1) にあたる $200 \mathrm{~kg}$ を抜き取りで採取し, 混合機で均一に混合 した。そのため, 製造飼料の全体の組成平均值は 実測出来たと判断している。それにあ関わらず, 素材個々の成分実測值（表 4）に基づいた組成の 設計值（表 7, (3)）と実測值（表 7, (4)）が必ずし も一致しなかったことは, 個々の素材の実測をし た場合にそのサンプリングエラーが伴ったことを 示している。そのため，フィールドに打ける抜き 取り式のサンプリングによる素材の実測值（表 4) を基にして，組成・栄養価の予測を行った場合で 屯, 組成予測精度の向上は, 今回の場合のように, 限界があることを考慮するべきであろう。

結論として，1 日に数百キロ程度の小規模な食 品残さの飼料利用を考えた配合設計をする場合の 栄養価推定は以下のように考える。

1. 飼料成分表に記載されていない素材につい ては，食品成分表から抽出した組成を用い ることで，推定は可能である。

2. 素材を実際にサンプリングして分析する場 合は, サンプリングエラーおよび日間, ロット間の変動に留意する必要がある。ア ミノ酸に関しては, 素材の変動と誤差を加 味した安全率を見込んでおく必要がある。 TDN については $3 \%$ 単位程度の誤差が 生じる。 
3. 以上のように現実対応するとともに，日本 食品標準成分表で扱っているヒトの可食部 の組成だけではなく，不食部の成分・栄養 価を明らかにしておくことあ必要であろ う。それらのデー夕の蓄積・充実を望みた い。

\section{謝辞}

素材として用いた食品残さの入手・運搬につい て，ビール粕は (有)依田商事，その他の素材は (株)クリーンサービスの協力を受けた。消化試験 実施時には, 畜産草地研究所の斎藤守氏之, 秋田 富士科長をはじめとする業務第 2 科の諸氏から多 大な援助を受け，分析については花木干穂氏，岡 部陽子氏に援助頂いた。以上の諸氏に感謝致しま す。

\section{文献}

1）堀北哲也：「飼料給与法」，生産獣医療シス テム養豚編, 133-135, 社団法人農山漁村文 化協会, 東京, 2000 .

2）独立行政法人農業技術研究機構: 日本標準 飼料成分表 2001 年版, 東京, 2001.

3）科学技術庁資源調査会編：日本食品標準成 分表の改訂に関する調査報告（五訂日本食 品標準成分表), 科学技術庁資源調査会報 告第 124 号, 大蔵省印刷局, 東京, 2000 .

4）社扵法人畜産技術協会 - 社団法人全国養豚 協会：リキッドフィーディング実用化平成 13 年度報告書. 東京. 2001 .

5）農林水産省大臣官房統計情報部編：平成 14 年畜産物生産費, 206-209. 財団法人農 林統計協会, 2003.

6）藤沢 武: 札幌市における事業系生ごみの リサイクルシステム, 廃棄物学会誌. 11 , 355-365, 2000.

7）佐伯真魚 - 北川順矩 - 松本光洋 - 西山厚 志・三好久美子・望月めぐみ・高須茜美 ・ 阿部 亮: 都市厨芥飼料の化学組成之栄養 価，日畜会報，72，J 34-40，2001.

8）科学技術庁資源調査会編：四訂日本食品標 準成分表のフォローアップに関する調査報
告 (改訂日本食品アミノ酸組成表), 科学技 術庁資源調査会報告第 87 号，大蔵省印刷 局，東京，1986.

9）農林水産省大臣官房統計情報部編：第 76 次農林水産省統計表（平成 11 年-12 年), 637-639, 財団法人農林統計協会, 東京, 2002.

10）農林水産省大臣官房統計情報部編 : 第 76 次農林水産省統計表（平成 11 年-12 年), 572-581，財団法人農林統計協会，東京， 2002.

11）丹羽美次 - 矢後啓司 - 音成洋司 - 阪上 泉・大澤貴之・佐伯真魚・奈良 誠・稗田 哲也・高須茜美・堀与志美・阿部 亮 : 都 市厨芥発酵乾燥製品の調製法と養豚飼料と しての栄養価, 日豚会誌, 40, 1-7, 2003.

12）大澤貴之・奈良 誠・矢後啓司・阿部 亮： 「肉豚肥育 $100 \%$ 給餌可能な残さ発酵飼料 の開発とその実証」, 中小食品産業・ベン チャ一育成技術開発支援事業成果発表会概 要集, 144-145, 財団法人食品産業セン 夕一, 東京, 2001.

13）藤田泰仁：「飼料の化学分析」，改訂粗飼料 の品質評価ガイドブック（自給飼料品質評 価研究会編), 5-18, 社団法人日本草地畜産 種子協会，東京，2001.

14）久米新一:「ミネラル」, 改訂粗飼料の品質 評価ガイドブック（自給飼料品質評価研究 会編), 20-24, 社団法人日本草地畜産種子 協会, 東京, 2001.

15）武政正明：リン酸カリ試薬による酸化クロ 么定量法の改良, 畜産試験場研究報告, 52, 7-13, 1992.

16）大澤貴之 - 亀井勝浩 - 丹羽美次 - 金 一 • 川島知之 - 佐伯真魚 - 堀与志美 - 矢後啓 司・阪上 泉・音成洋司・阿部 亮: 食品 循環資源の利用による高品質豚肉肥育技術 の開発に関する研究，日豚会誌，41，207$216,2004$.

17）佐伯真魚・伊賀亜沙子・鈴木由貴子・砂川 直子・阿部 亮: 各種都市厨芥乾燥飼料に おける粗タンパク質の消化特性とタンパク 質画分，日畜会報，73，J 423-429， 2002.

18）農林水産省農林水産技術会議事務局：日本 飼養標準・豚 (1998年版), 106, 東京. 1998. 


\title{
Validation of Chemical Composition and Nutritive Value of Feed for Swine Formulated from Co-products According to the Values Derived from the Standard Tables of Food and Feed Composition
}

\author{
Mao Sayeki $^{1}$, , Tomoyuki Kawashima ${ }^{1)}$, Takayuki Ohsawa ${ }^{2)}$, Izumi Sakagami ${ }^{2)}$, \\ Hiroshi Otonari ${ }^{2)}$, Toshihiro Takahashi' ${ }^{1)}$, Yoshitsugu Niwa ${ }^{3)}$, Tatsuki Mochizuki ${ }^{3)}$, \\ Shinpei Yamamoto ${ }^{3)}$, Keiichi Watanabe ${ }^{3)}$, Keiji Yago ${ }^{4)}$, Minoru Aoki ${ }^{5)}$, Yoshimi Hori ${ }^{5)}$, \\ Ryozo TAKAdA ${ }^{1)}$, Makoto YamazAKI ${ }^{1)}$, Osamu ENISHI ${ }^{1)}$ and Akira $\mathrm{ABE}^{3)}$ \\ 1) National Institute of Livestock and Grassland Science, Tsukuba-shi, Ibaraki, 305-0901 \\ 2) Pure Pork Ltd. 1616-2 Okazaki, Hiratsuka-shi, Kanagawa, 259-1212 \\ 3) Nihon University, College of Bioresource Sciences, 1866 kameino, Fujisawa-shi, \\ Kanagawa, 252-8510 \\ 4) Research Institute for Animal Science in Biochemistry \& Toxicology, 3-7-11 \\ Hashimoto-dai, Sagamihara-shi, Kanagawa, 229-1132 \\ 5) Livestock Industry Research Institute, Kanagawa Prefecture, 3750 Hongo, Ebina-shi, \\ Kanagawa, 243-0417
}

Three types of feed exclusively for pigs were formulated from co-products using the values derived from the Standard Tables of Food and Feed Composition. From this formulation, co-products, i.e. rice, bread, noodles, rye bran, brewers residue grains, fish, soybean curd, soybean curd residue, and vegetables, were collected in Hiratsuka city, Kanagawa Prefecture with each type of feed produced under a fermentation-dehydration system which took more than 45 days. The total amount of each co-product feed manufactured was more than $900 \mathrm{~kg}$. The feed was subjected to chemical analyses and digestion trials using 15 LWD pigs (average BW $47.2 \mathrm{~kg}$ ). The results were then compared to the formulation values. It was shown that the application of values of certain co-products derived from the Standard Tables of Food Composition was effective in formulating feed, in cases where the value was not described in the Standard Tables of Feed Composition. It is necessary to formulate feed under safety factor considerations as the lysine content analyzed was small compared to the formulated lysine content, with $\mathrm{a} \pm 3$ point gap separating the analyzed and formulated nutritive values. Accuracy of formulation was not improved by the application of analyzed values of DM and chemical composition of partially obtained samples, due to sampling errors.

Jpn. J. Swine Science, 41, $4: 217-227$

Key words : Co-product, Estimation of composition, Nutritive value, Standard tables, Food waste 